\title{
Vortex Generators Project for an Unmanned Small Airplane
}

João Barreto Duarte Neto joaobarretomecufc@gmail.com

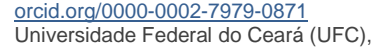
Fortaleza, Ceará, Brasil.

Maria Elisa Marciano Martinez melisa@inpi.gov.br

orcid.org/0000-0002-8010-869X Instituto Nacional da Propriedade Industrial (INPI), São Paulo, São Paulo, Brasil.

Marcello Carvalho dos Reis marcello@meteora.com.br Meteora, Fortaleza, Ceará, Brasil.

Claus Franz Wehmann claus.wehmann@ufc.br orcid.org/0000-0001-8756-9387 Universidade Federal do Ceará (UFC), Fortaleza, Ceará, Brasil.

\begin{abstract}
Since the Cold War period, turbine generators have proved to be an important alternative to the development of aerodynamic aircraft designs, and even so, there was little adherence to their use, among which we highlight, short takeoff and landing aircraft (STOL) and some models of military aircraft and commercial jet aircraft. In the USA and Brazil, in addition to other countries, they hold competitions to awaken technological innovation in the aeronautical field for engineering students: the SAE AeroDesign Competition (SAE - Society of Automotive Engineers). These contests allow teams from their countries to use points of difference in their design and, in some cases, to use small unmanned aircraft devices that have already been designed for huge aircraft, such as vortex generators. Therefore, we intend to adopt a Vortex Generator model for the Avoante Aeromec AeroDesign team airplane project (team from the Federal University of Ceara, Brazil - UFC), use Computational Fluid Dynamics (CFD) with turbulence modeling, as well as perform tests in a wind tunnel. Despite the problems found in comparing the results of the computational models with the prototype tests, it was possible to prove the efficiency of these vortex generators in the design of the team's airplane, observing the increase in the stall angle, reduction of the drag coefficient and increase of the coefficient lifting.
\end{abstract}

Keywords: Vortex Generators; Wing; CFD; Prototypes. 


\section{INTRODUCTION}

In aircraft designs, we always take into account how the air behaves when the aircraft is subjected to different conditions. In the case of aircraft designs, these conditions can vary considerably, given that all the variables that make the flight process possible can be changed drastically, and if the project does not provide for them, the final product - the aircraft or plane - will have a high risk of failure, that is, an accident. For example, an airplane must be prepared for the takeoff, cruise and landing phases, although the potential gust and rain conditions must also be considered because they are extreme with regard to the aerodynamics and stability of the project (ANDERSON Jr., 2001).

In the USA and Brazil, in addition to other countries, they hold competitions to awaken technological innovation in the aeronautical field for engineering students: the SAE AeroDesign Competition (SAE - Society of Automotive Engineers). These contests allow teams from their countries to use points of difference in their design and, in some cases, to use small unmanned aircraft devices that have already been designed for huge aircraft, such as vortex generators.

In aircraft designs, the use of devices that improve the aerodynamic efficiency and stability of the aircraft are considered, above all, the aerodynamic part must observe the air flow above and below its wing. This air that is closest to the wing surfaces is not moving evenly, this is a thin layer to which the fluid's viscosity affects its flow, known as the boundary layer. This layer influences the variation of force acting on the lifting surface, especially changing the stall and drag properties. Generally, he tried to prevent it from flowing off the surface, because that would greatly change the pressure distribution configuration thought of in the wing design; this new distribution can considerably affect the aircraft's flight and its external structure (GROSS; FASEL, 2018; LAMBERT; RAZAK; DIMITRIADIS, 2017; DURDEN, 2014).

Based on these observations, the vortex generators were designed as small devices that would prevent stall and turbulence, increasing the interaction between the fluid layers that flow alongside the wing surface, which maintain this flow in this region even at high angles attack (AoA). Vortex generators (VGs) are devices placed on the elevation surfaces of an aircraft (DURDEN, 2014; CALLE, 2015) - especially on the wing - to prevent the displacement of the boundary layer and, thus, increase the stall angle, improve the stability and shorten landing and takeoff runway lengths. They work by creating a small vortex that generates a secondary flow that avoids the loss of moment of the flow and its displacement from the wing surface (DUARTE NETO, 2019). These vortices will cause the air flow - more specifically the boundary layer - to mix and remain close to the upper wing surface, even at high angles of attack, thus increasing the stall angle. This behavior is used to decrease drag and increase the support of aerodynamic structures in several areas, for example, wind energy (BALDACCHINO et al., 2018), marine engineering (AHMED, ELBATRAN; SHABARA, 2014) and the automotive industry (LÖGDBERG, 2006).

The ability of VGs to reduce drag is of interest to small planes such as unmanned aerial vehicles (UAVs) due to the limitations inherent in these devices, 
such as engine power, battery, fuel tank size, weight, among other variables. Therefore, some dedicated solutions are developed using passive devices such as VGs (ZHEN; ZUBAIR; AHMAD, 2011; MARQUES; BACHOUCHE; MALIGNO, 2013; PAIBOOLSIRICHIT, 2016; UDARTSEV; ROZBYTSKYI; SATTAROV, 2018; SATTAROV et al., 2019). In the case of competition, such as SAE Aerodesign, much effort is devoted to the development of radio controlled airplanes for the best performance (MIYADAIRA; CASTRO NETO; CARVALHO, 2018; COSTA et al., 2018; LEHMKUHL; MARIGA; OLIVEIRA Jr., 2018; REIS et al., 2018), with the objectives being short takeoff length, landing and takeoff weight (WTO). There are different strategies used by the teams, some of them use the reduction of induced drag (REIS et al., 2018; TURCATO et al., 2018) and, more recently, the suggested VGs (MELO; MARIANO, 2019). The main problem addressed in this work is to adopt a VG design for the Avoante Aeromec AeroDesign team's airplane design, using turbulence models in CFD and wind tunnel tests, since this use of technology is a matter of commitment and, as pointed out by Baldacchino et al. (2018), not always effective.

\section{MATERIALS AND METHODS}

In the prototypes made, the CAD software was used for drawing the drawings and, for the analysis, the CFD software. All dimensions shown in these two software are in the millimeter scale.

\section{PROJECT}

To compare the results found in this study with the results of (MELO et al., 2019), it was used both in the analysis of the CFD and test in a wind tunnel whose wing had a wingspan of $400 \mathrm{~mm}$ whose rope with the value of the aerodynamic mean chord - or CMac -, that is, $382.22 \mathrm{~mm}$, and the control volumes were designed with this chord value using the Mullen (2019) and Cornell University (2015) procedure proposal for flow analysis. The two-dimensional drawing (2D) is presented with its dimensions in Figures $\mathbf{1} \mathbf{a}-\mathbf{b}$.

Figure 1 - Dimensioned drawing of the 2D control volume. a) Limits and external dimensions; (b) Smaller division of the control volume with its dimensions

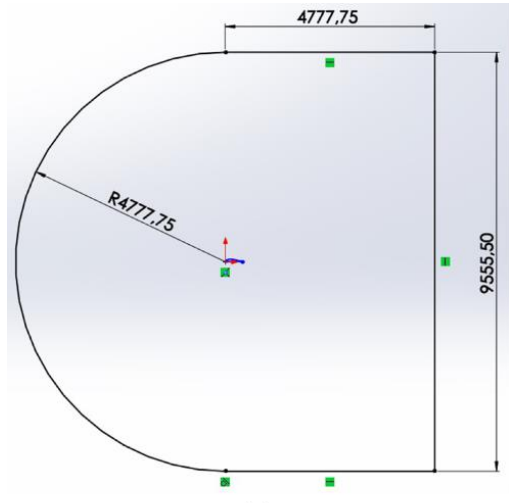

(a)

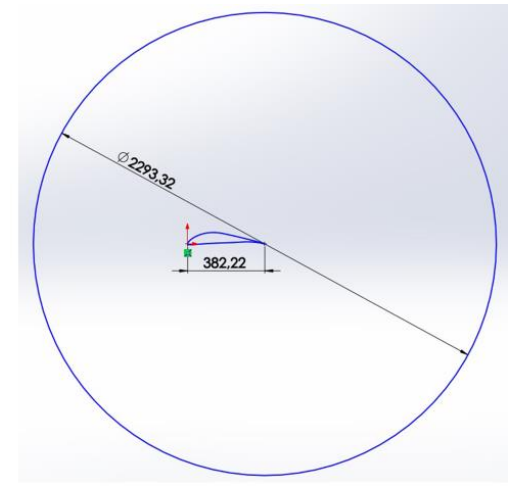

(b)

Source: author. 
As the objective was to verify the difference of the VGs in relation specifically to the airfoil, it compares the 2D calculations of the airfoil without VGs with the three-dimensional (3D) analysis of the airfoil with VGs. This method was worked on in Sørensen, Zahle and Vronsky (2014), which uses an opposite rotation configuration and explores geometric symmetry by simulating only one of the reeds. In contrast, this work simulated an entire group of VGs for a complete wingspan.

The 3D is shown in Figure $\mathbf{2}$ (with the same dimensions as the 2D, but with a width of $400 \mathrm{~mm}$ - the same measurement of the wingspan), because the purpose of this analysis was to compare these results with the results of the tunnel wind).

Figure 2 - Design of the 3D control volume

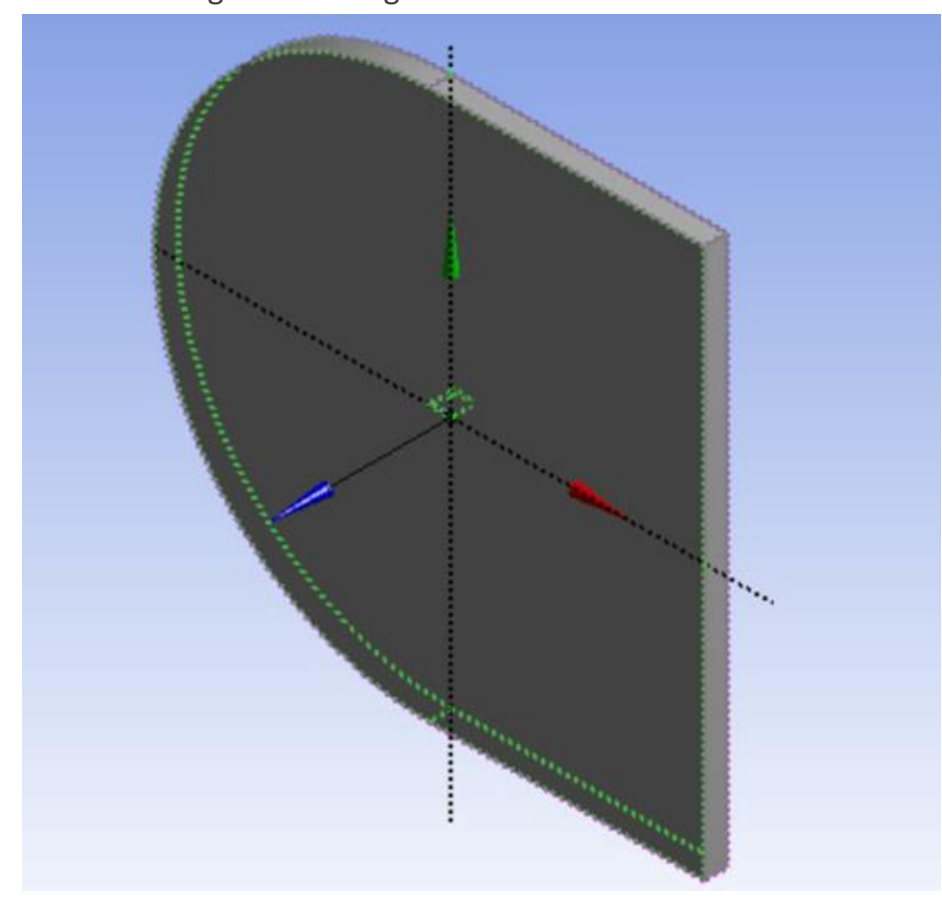

Source: author.

Aerodynamic analyzes used the turbulence model known as SpalartAllmaras, as suggested by Cornell University (2015), which was designed and optimized for wing and airfoil flows and produced favorable results without the gradation of the use of computational tools. These analyzes were performed for four different speed values $(7.33 \mathrm{~m} / \mathrm{s}, 10.45 \mathrm{~m} / \mathrm{s}, 15.32 \mathrm{~m} / \mathrm{s}$ and $16 \mathrm{~m} / \mathrm{s})$, and for each speed the angles from $0^{\circ}$ to $25^{\circ}$ (ranging from $5^{\circ}$ to each other), in addition to the stall angle, incidence angle, climbing angle and minimum angle described in Melo et al. (2019).

For the analyzes with the GPs, the model used by Sørensen, Zahle and Vronsky (2014) was chosen, with the format of Figure $\mathbf{3}$ and the dimensions of Figure 4. 
Figure 3 - Configuration of the VGs used by Sørensen, Zahle and Vronsky (2014)

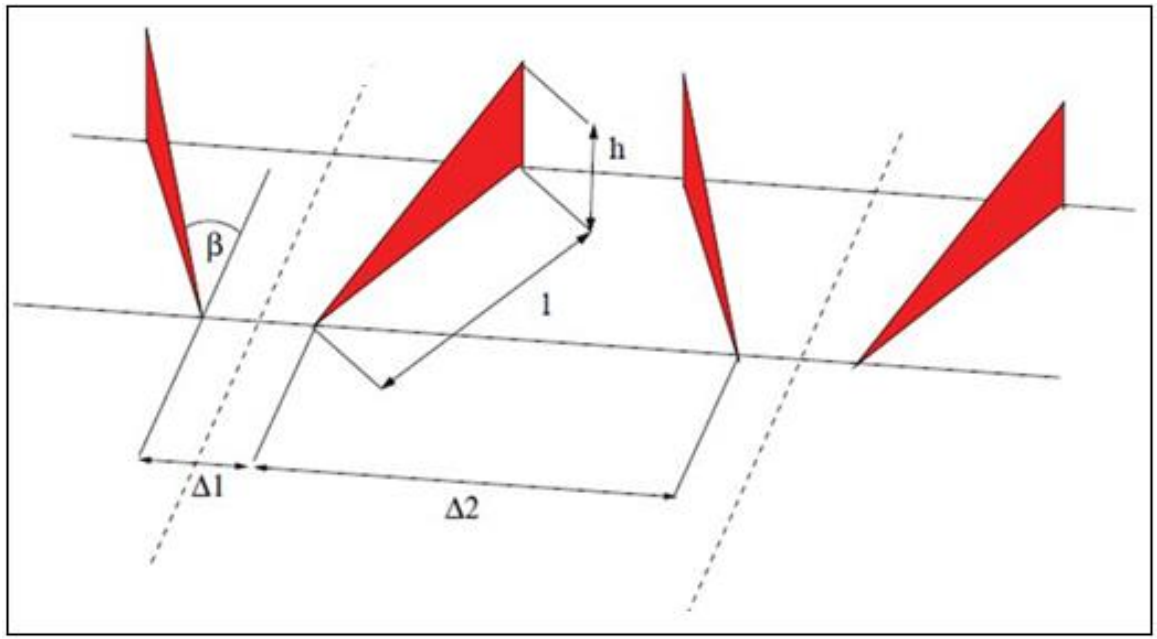

Source: author.

The execution model chosen was the most relevant, as pointed out by Fouatih et al. (2016) and Kumar et al. (2016), given that the counter-rotating device appears as the most effective agreement with Godard and Stanislas (2006), and was also used in this study.

Figure 4 - Dimensions of a single VG

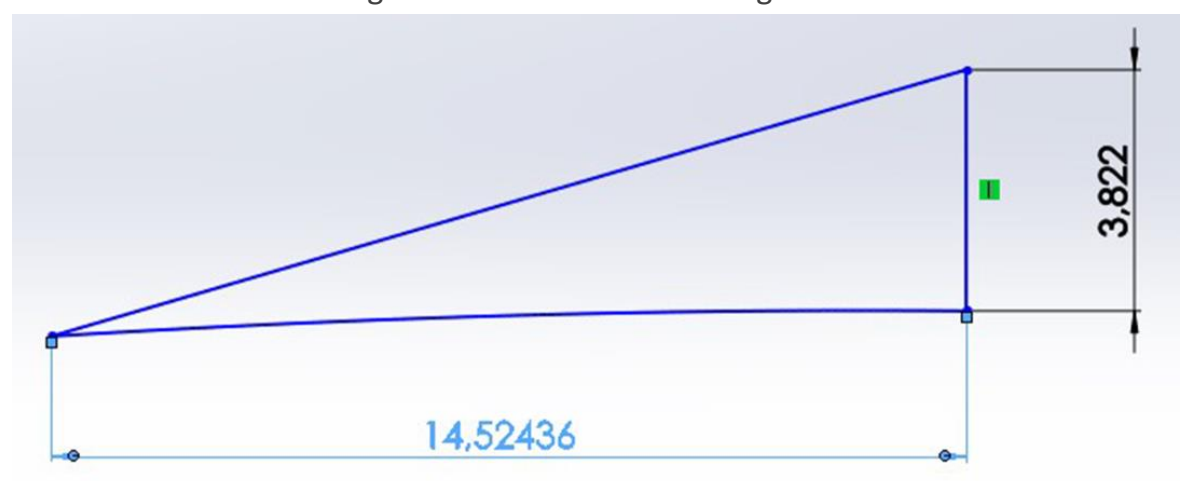

Source: author.

The positioning configuration for the entire wing extension follows in Figure 5, with the distances proportional to the airfoil chord value; as in Sørensen, Zahle and Vronsky (2014):

[...] the height ( $h$ ) of the VG is 1 percent of the chord length, the aspect ratio $(\mathrm{I} / \mathrm{h})$ of the VG is approximately 3.8 and the inclination with the incoming flow $(\beta)$ is 15.5 degrees, the distance between the VG within the pairs is $\Delta 1 / \mathrm{h} \sim 5$ at the leading edge of the VG, while the distance at the leading edge to the next VG pair is $\Delta 2 / \mathrm{h} \sim 4$. 
Figure 5 - VGs' positioning configuration

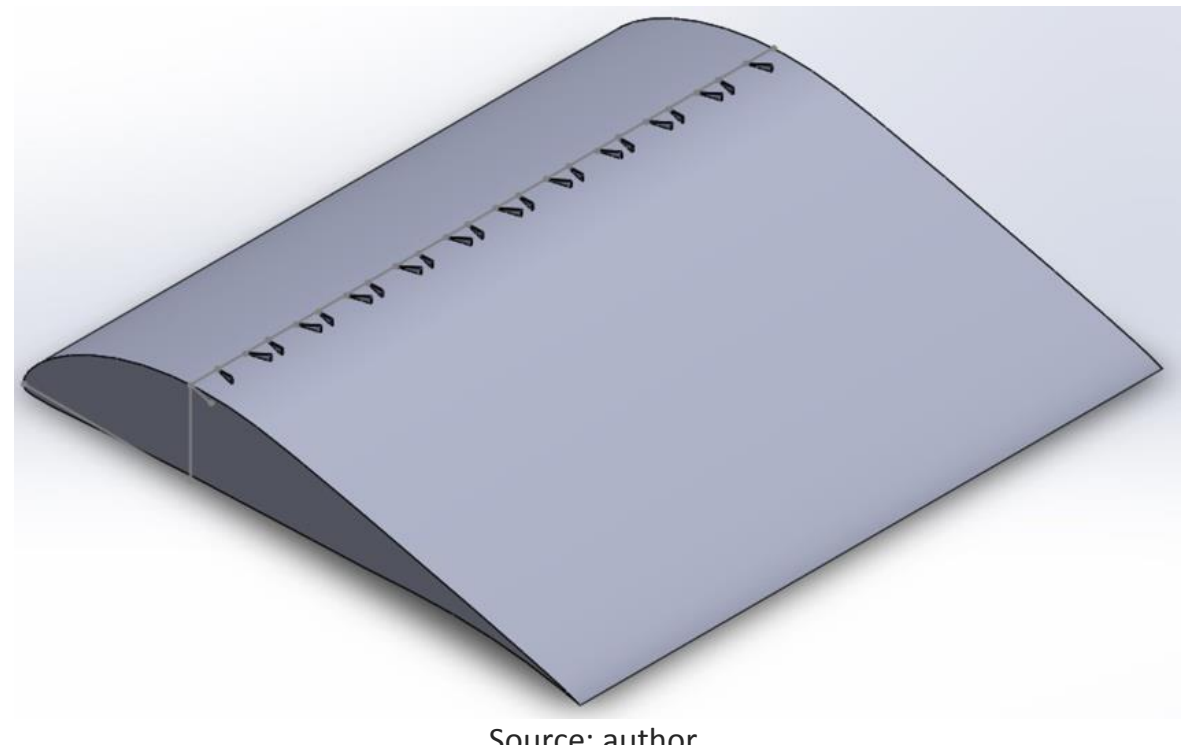

Source: author.

\section{PROTOTYPES}

The wing was the same used by Melo et al. (2019), just with some repairs, as it is introduced in Figure 6.

Figure 6 - Wing used in the wind tunnel tests

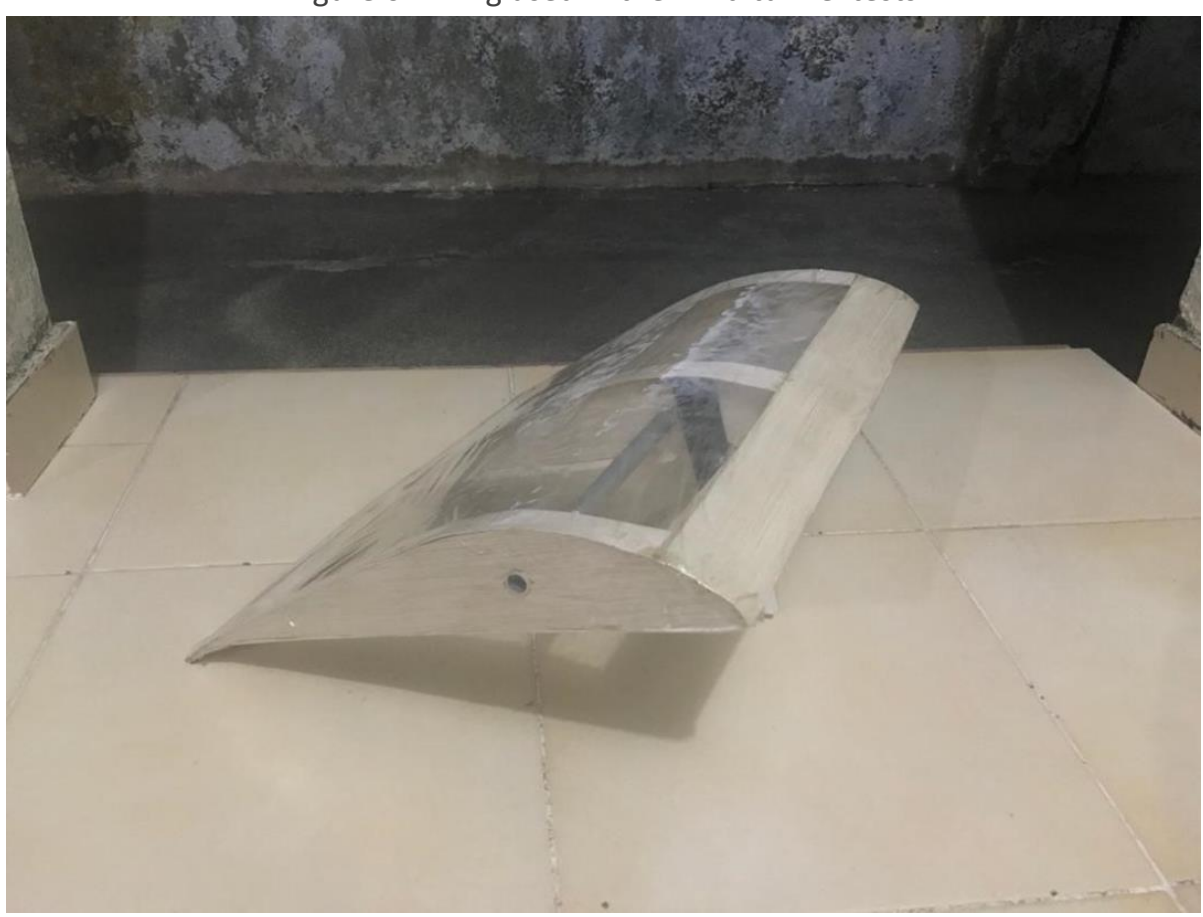

Source: author.

The manufacture of the VGs was made in a 3D printer using ABS (acrylonitrile butadiene styrene - plastic material) with later adjustment using sandpaper to remove the imperfections, as seen in Figures $\mathbf{7 a - b}$. 
Figure 7 - VGs made in the 3D printer: (a) Set of VGs after the print; (b) A single VG after the imperfections' removal

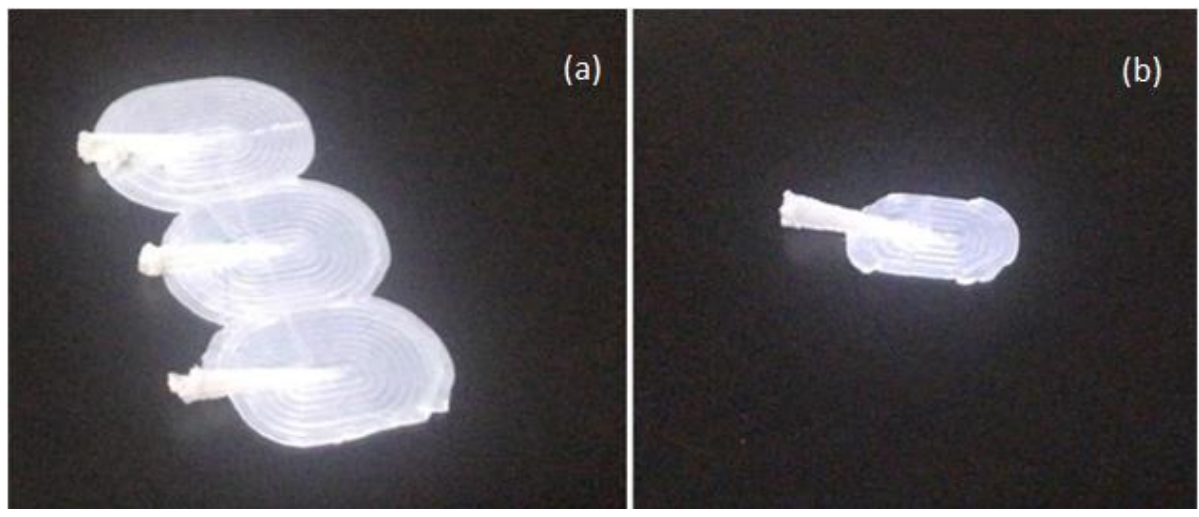

Source: author.

Tests were made in the wind tunnel (shown in Figure 8) in Federal University of Ceara with the same aerodynamic scales utilized by Melo et al. (2019).

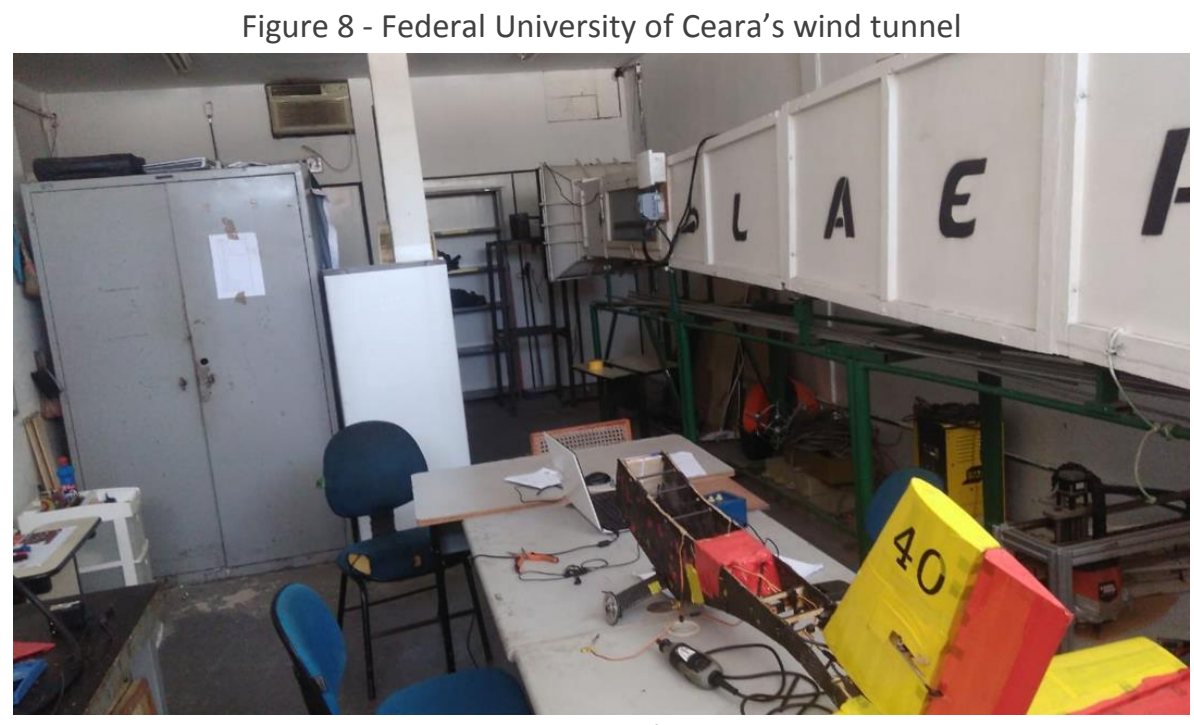

Source: author.

The wing remained attached to the upper end of the scales (Figure 9); in this case, there were two sensors that read the deformations due to lift and drag on the wing. Speed was measured by an anemometer (shown on the left side of Figure 9).

The tests were done with the same angles of the analyzes and speeds at which the tests were carried out were $7.33 \mathrm{~m} / \mathrm{s}$ and $10.45 \mathrm{~m} / \mathrm{s}$, the first being the minimum speed of the unmanned airplane and the second is the takeoff speed. 
Figure 9 - Aerodynamic scales used in the tests

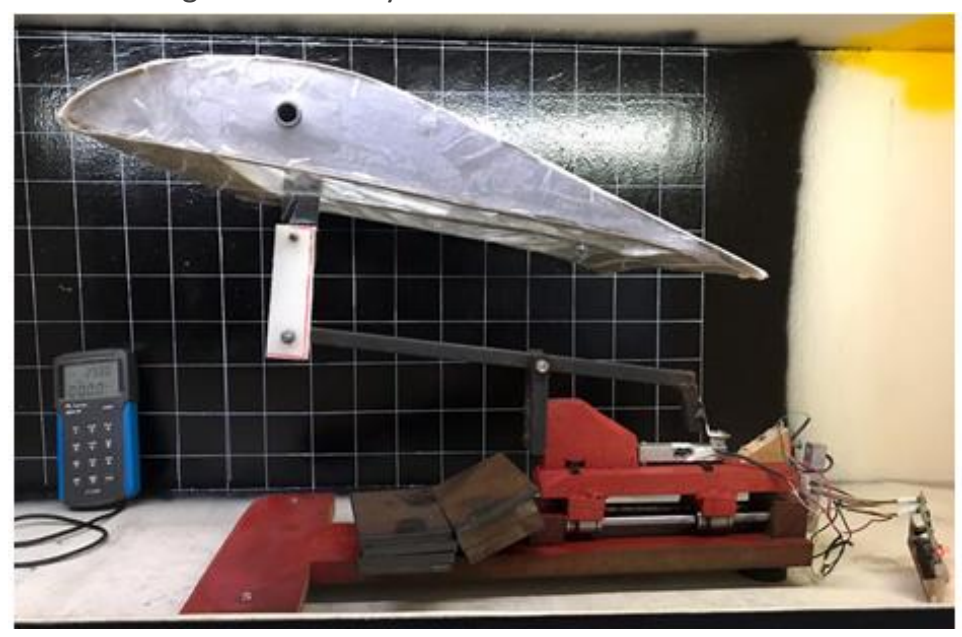

Source: author.

\section{RESULTS AND DISCUSSION}

There were made the graphs $C_{L} \times A_{\circ} A$ and $C_{D} \times A_{\circ} A$ to each one of the velocities in the CFD's analyses and in the wind tunnel tests. The Figures 10 to 13 follow with their labels:

Figure 10 - Graphs of the CFD analyses for the cruise speed (16 m/s): (a) Lift coefficient $x$ angle of attack; (b) Drag coefficient $x$ angle of attack

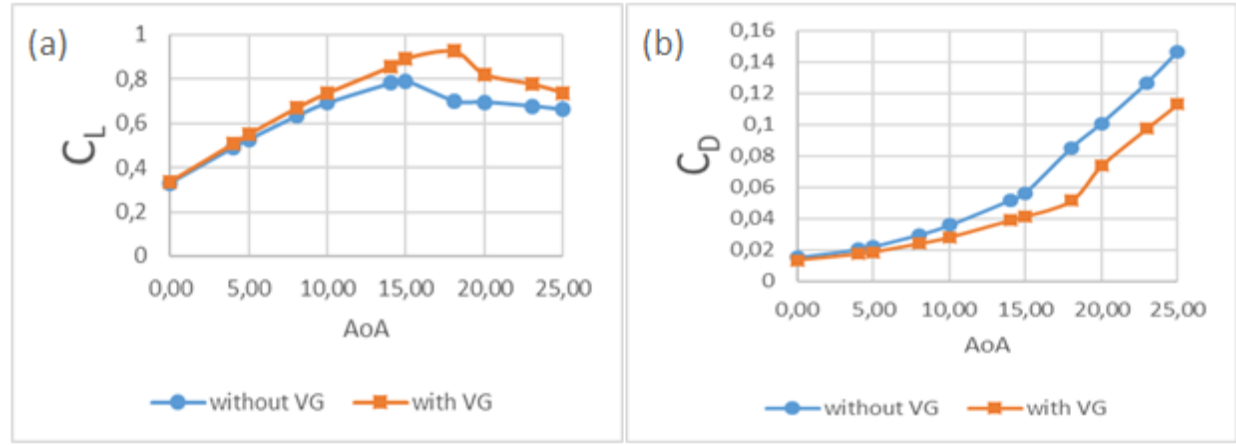

Source: author.

Figure 11 - Graphs of the CFD analyses for the take-off speed (15.3258 m/s): (a) Lift coefficient $x$ angle of attack; (b) Drag coefficient $x$ angle of attack

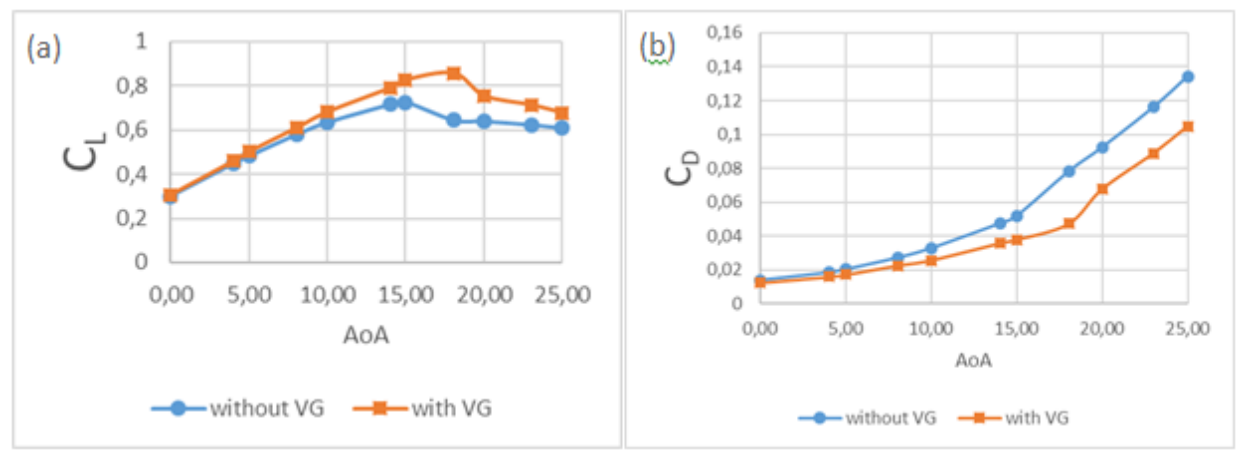

Source: author. 
Figure 12 - Graphs of the CFD and wind tunnel analyses for the stall speed $(10.45 \mathrm{~m} / \mathrm{s})$ :

(a) Lift coefficient $x$ angle of attack; (b) Drag coefficient $x$ angle of attack

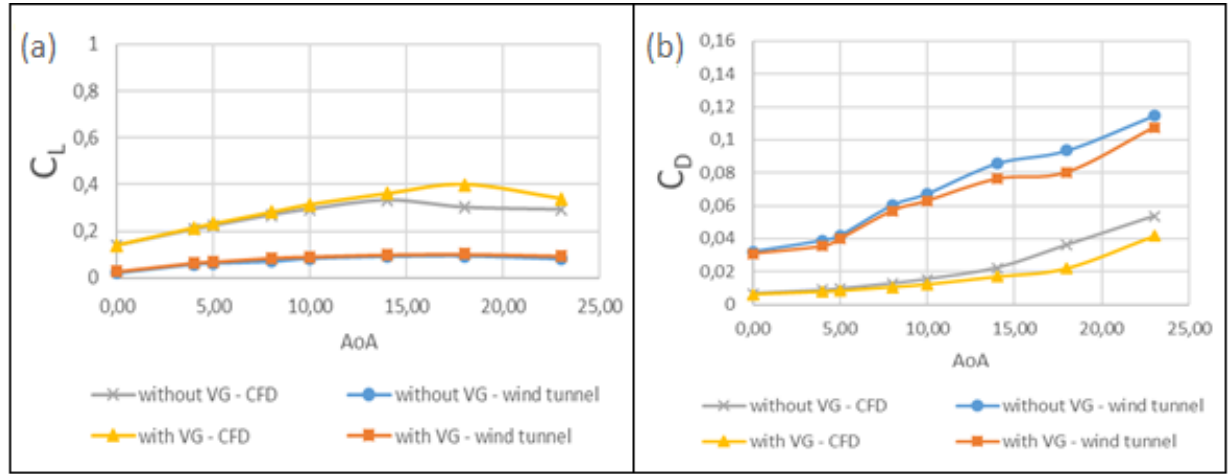

Source: author.

Figure 13 - Graphs of the CFD and wind tunnel analyses for the minimum speed (7.33 $\mathrm{m} / \mathrm{s}$ ): (a) Lift coefficient $\mathrm{x}$ angle of attack; (b) Drag coefficient $\mathrm{x}$ angle of attack

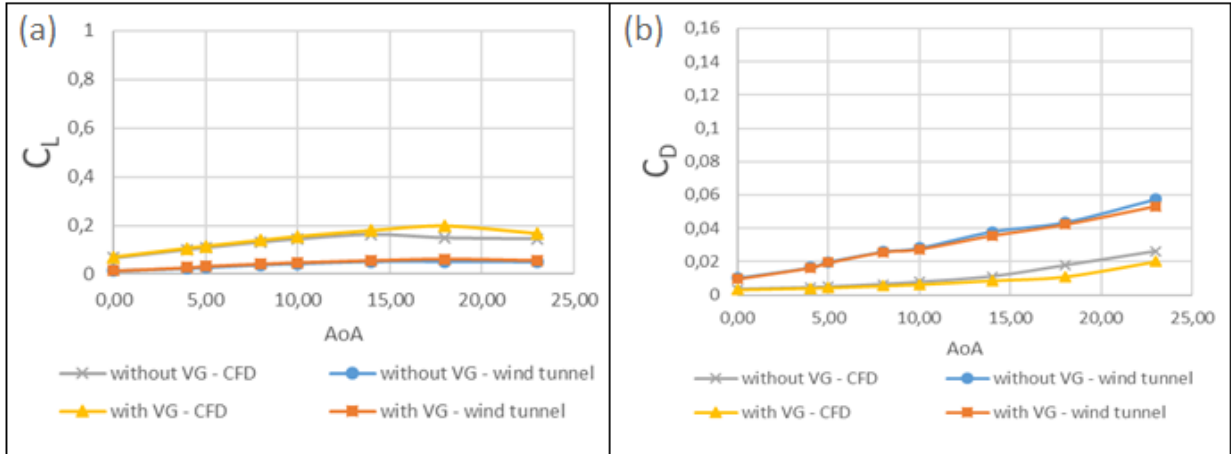

Source: author.

The results were consistent with those proposed by Sørensen, Zahle and Vronsky (2014) and Seshagiri, Cooper and TRAUB (2009) given that for the speeds used, the VGs made the drag decrease and the lift increase, with an increase of $30 \%$ in the CFD model and $12,5 \%$ under test in the wind tunnel. These results are in agreement with Seshagiri, Cooper and TRAUB (2009) if the differences in angles used in both studies are considered.

The drag reduction was measured in the CFD model in the last $40 \%$, and the same was not observed in the wind tunnel test, since the drag in the wind tunnel test includes induced drag and in the CFD, it does not. In the analysis carried out, a $2 \mathrm{D}$ model was used, despite having the same shape transversely, in wingspan it is different from the real wing of the project, which contradicts the similarity of flow presented by Anderson Jr. (2001) and Fox, McDonald and Pritchard (2011) and, as expected, the lifting is greater and the drag less, as shown by Anderson Jr. (2001) and Calle (2015). In the end, it was identified that the same in all tested speeds.

With the CFD data, it was possible to observe that the greater the angle, the greater the difference made by the VGs, at least up to the stall angle, this was observed in different types of VGs, as demonstrated by Kerho et al. (1993), and, Barrett and Farokhif (1996), and with similar effectiveness. This behavior was also demonstrated in a wind tunnel test, with maxima close to the stall angle with a 
difference of $12.5 \%$ for a lower speed and $16 \%$ close to $10^{\circ}$ for a speed of 10.45 $\mathrm{m} / \mathrm{s}$. Both situations are essential for the developed prototype, because in addition to avoiding the stall and it actually occurs at the angle designed for takeoff.

\section{CONCLUSIONS}

With this study and prototype development, it was possible to compare the wings of unmanned airplanes with and without vortex generators, both in CFD and in wind tunnel tests, even with the use of 2D analysis and the nonconsideration of drag from the tip of the wing, it was noted that the goal was achieved with the VGs.

It was also observed that the VGs increased the stall angle of the airfoil for all cases, as in the CFD and in the wind tunnel test, increased the lift, especially at greater angles, as well as reduced drag. The CFD analysis showed that the use of the VG could increase the increase in the last $30 \%$ and reduce drag in the last $40 \%$ in the best scenario. The wind tunnel test finally showed a $16 \%$ better lift, even if the reduced drag was negligible.

The same behavior had already been observed by other authors (SESHAGIRI; COOPER; TRAUB, 2009; SØRENSEN; ZAHLE; VRONSKY, 2014; ZHEN; ZUBAIR; AHMAD, 2011; PAIBOOLSIRICHIT, 2016). These results confirm that the use of the methodology described by Sørensen, Zahle and Vronsky (2014), even if it was not developed for small-scale aircraft like UAV, fits the proposed improvement of aerodynamic characteristics and performance in the developed prototype. The difference in 2D CFD and Experimental data in wind tunnel test $t$ results from limitations as it is a 2D flow analysis in computational analysis. As expected, the $C L$ and the $C D$ are the same for an airfoil and the wind tunnel test was carried out with a small wing, which, however good the approach is. It is worth mentioning that the wind tunnel tests showed drag values considerably higher than those of the CFD, since the drag of the wing tip (induced drag) is dominant in the results in the wind tunnel test. 


\section{Projeto de geradores de vórtice para um pequeno avião não tripulado}

\section{RESUMO}

Desde o período da Guerra Fria, os geradores de turbinas têm se mostrado uma importante alternativa para o desenvolvimento de projetos de aeronaves aerodinâmicas e, mesmo assim, houve pouca adesão ao seu uso, entre os quais destacamos: aeronaves de decolagem e aterrissagem curta (STOL) e algumas modelos de aeronaves militares e aviões comerciais a jato. Nos EUA e no Brasil, além de outros países, realizam competições para despertar a inovação tecnológica no campo aeronáutico para estudantes de engenharia: o SAE AeroDesign Competition (SAE - Sociedade de Engenheiros Automotivos). Esses concursos permitem que as equipes de seus países usem pontos de diferença em seu design e, em alguns casos, usem pequenos dispositivos de aeronaves não tripuladas que já foram projetados para aeronaves enormes, como geradores de vórtice. Portanto, pretendemos adotar um modelo de Gerador de Vórtice para o projeto de avião em equipe da Avoante Aeromec AeroDesign (equipe da Universidade Federal do Ceará, Brasil - UFC), usar a Dinâmica dos Fluidos Computacional (CFD) com modelagem de turbulência e realizar testes em um túnel de vento. Apesar dos problemas encontrados na comparação dos resultados dos modelos computacionais com os testes de protótipo, foi possível comprovar a eficiência desses geradores de vórtice no projeto do avião da equipe, observando o aumento do ângulo de estol, a redução do coeficiente de arrasto e aumento do levantamento do coeficiente.

PALAVRAS-CHAVE: Geradores de Vórtice; Asa; CFD; Protótipos. 


\title{
Proyecto de generadores de vórtice para un pequeño avión no tripulado
}

\begin{abstract}
RESUMEN
Desde el período de la Guerra Fría, los generadores de turbinas han demostrado ser una alternativa importante al desarrollo de diseños de aviones aerodinámicos, y aun así, hubo poca adherencia a su uso, entre los que destacamos, los aviones de despegue y aterrizaje cortos (STOL) y algunos modelos de aviones militares y aviones comerciales. En los EE. UU. Y Brasil, además de otros países, realizan concursos para despertar la innovación tecnológica en el campo aeronáutico para estudiantes de ingeniería: el SAE AeroDesign Competition (SAE - Sociedad de Ingenieros Automotrices). Estos concursos permiten a los equipos de sus países usar puntos de diferencia en su diseño y, en algunos casos, usar pequeños dispositivos de aviones no tripulados que ya han sido diseñados para aviones enormes, como los generadores de vórtice. Por lo tanto, tenemos la intención de adoptar un modelo de generador de vórtice para el proyecto de avión del equipo Avoante Aeromec AeroDesign (equipo de la Universidad Federal de Ceará, Brasil - UFC), utilizar la dinámica de fluidos computacional (CFD) con modelado de turbulencia, así como realizar pruebas en un túnel de viento. A pesar de los problemas encontrados al comparar los resultados de los modelos computacionales con las pruebas de prototipo, fue posible demostrar la eficiencia de estos generadores de vórtices en el diseño del avión del equipo, observando el aumento en el ángulo de pérdida, la reducción del coeficiente de arrastre y aumento del coeficiente de elevación.
\end{abstract}

PALABRAS CLAVE: Generadores de Vórtices; Ala; CFD; Prototipos. 


\section{REFERÊNCIAS}

AHMED, Y. M.; ELBATRAN, A. H.; SHABARA, H. M. Study of the effect of low profile vortex generators on ship viscous resistance. Journal of Ocean, Mechanical and Aerospace - Science and Engineering -, vol. 3, p. 8-14, 2014. Available at: <http://isomase.org/JOMAse/Vol.3\%20Jan\%202014/3-2.pdf>. Accessed on March 2, 2019.

ANDERSON Jr., J. D. Fundamentals of Aerodynamics. Third Edition. New York: McGraw-Hill, 2001. 912 p.

BALDACCHINO, D.; TAVERNIER, C. F. D.; TIMMER, W.; VAN BUSSEL, G. J. Experimental parameter study for passive vortex generators on a $30 \%$ thick airfoil. Wind Energy, v.21, n.9, p.745-765, 2018. DOI: https://doi.org/10.1002/we.2191

BARRETT, R.; FAROKHIF, S. Subsonic aerodynamics and performance of a smart vortex generator system. Journal of Aircraft, v. 33, n.2, p.393-398, 1996. DOI: https://doi.org/10.2514/3.46950

CALLE, O. L. Preliminary study of the effects of vortex generators in ultralight aircraft, 2015, 81f. (Grau en Enginyeria en Tecnologies Aeroespacials (GRETA)) Escola Tècnica Superior d'enginyeries Industrial i Aeronàutica de Terrassa, Barcelona. Available at: <https://core.ac.uk/download/pdf/81579251.pdf>. Accessed on March 2, 2019.

CORNELL UNIVERSITY. SimCafe: Flow Over an Airfoil, Meshing. 2015. Video. Available at: <https://www.youtube.com/watch?v=Q-YzrOYwOHU>. Accessed on March 2, 2019.

COSTA, J. L. P.; ALVES, M. C.; TORRES, G. de O.; PAULINYI, L. F. de A. Uma investigação numérica do efeito solo em asas sustentadoras à baixo Reynolds. $6^{\circ}$ FORUM SAE BRASIL AERODESIGN 2018. Sociedade de Engenheiros Automotivos, 2018.

DUARTE NETO, J. B. Projeto de Geradores de Vórtices para asa de uma aeronave a participar na Competição SAE Brasil AeroDesign. Universidade Federal do Ceará, Fortaleza, Brasil, 2019.

DURDEN, R. Vortex generators: 50 years of performance benefits. World's Premier Independent Aviation News Resource, March 9, 2014. Available at: 
$<$ https://www.avweb.com/ownership/vortex-generators-50-years-ofperformance-benefits/>. Accessed on March 2, 2019.

FOUATIH, O. M.; MEDALEB, M.; IMINE; O.; IMINE, B. Design optimization of the aerodynamic passive flow control on NACA 4415 airfoil using vortex generators. European Journal of Mechanics B/Fluids, vol. 56, p. 82-96, 2016. DOI: https://doi.org/10.1016/j.euromechflu.2015.11.006

FOX, R. W.; McDONALD; A. T.; PRITCHARD, P. J. Introdução à Mecânica dos Fluidos. Seventh Edition. Rio de Janeiro: LTC, 2011. 728 p.

GODARD, G.; STANISLAS, M. Control of a decelerating boundary layer. Part 1: Optimization of passive vortex generators. Aerospace Science and Technology, vol. 10, n. 3, p. 181-191, 2006. DOI: https://doi.org/10.1016/i.ast.2005.11.007

GROSS, A.; FASEL, H. F., Active control of laminar separation: simulations, wind tunnel, and free-flight experiments. Aerospace, v. 5, n.4, p. 114, 2018. DOI: https://doi.org/10.3390/aerospace5040114

KERHO, M.; HUTCHERSON, S.; BLACKWELDER; R. F.; LIEBECK, R. H. Vortex generators used to control lamina separation bubbles. Journal of Aircraft, v. 30, n. 3, p. 315-319, 1993. DOI: https://doi.org/10.2514/3.46336

KUMAR, G.; NARAYANAN, K. S.; ARAVINDHKUMAR, S. K.; KUMAR, S. K. Comparative analysis of various vortex generators for a NACA 0012 aerofoil. International Journal of Innovative Studies in Sciences and Engineering Technology, v. 2, n. 5 p. 3-6, 2016. Available at: <http://ijisset.org/wpcontent/uploads/2016/05/IJISSET-020509.pdf>. Accessed on March 2, 2019.

LAMBERT, T.; RAZAK, N. A.; DIMITRIADIS, G. Vortex lattice simulations of attached and separated flows around flapping wings. Aerospace, v. 4, n. 2, p. 22, 2017. DOI: https://doi.org/10.3390/aerospace4020022

LEHMKUHL, R. A.; MARIGA, L.; OLIVEIRA Jr., A. A. M. Bancada experimental para medição de propriedades aerodinâmicas em ambiente aberto. $6^{\circ}$ FORUM SAE BRASIL AERODESIGN 2018. Sociedade de Engenheiros Automotivos, 2018.

LÖGDBERG, O. Vortex Generators and Turbulent Boundary Layer Separation Control. Technical Report from Royal Institute of Technology KTH Mechanics. Stockholm, Sweden, 2006, 118p. Available at: <http://kth.divaportal.org/smash/get/diva2:10933/FULLTEXT01.pdf>. Accessed on March 2, 2019. 
MARQUES, P.; BACHOUCHE, A.; MALIGNO, A. Aerodynamic evaluation of the Djebel Laassa UAV. International Journal of Unmanned Systems Engineering, v. 1, n. 1, p. 9-15, 2013. DOI: http://dx.doi.org/10.14323/ijuseng.2013.4

MELO, A. R. S.; PEREIRA, G. Â. G.; LIMA, G. L. G. D.; MEDEIROS, J. H. T. Relatório de Aerodinâmica - Avoante Aeromec. Universidade Federal do Ceará, Fortaleza, Brasil, 2019.

MELO, A. T.; MARIANO, F. P. Desenvolvimento de geradores de vórtices para aeronaves de pequeno porte. $1^{\circ}$ Simpósio Goiano de Engenharia Mecânica SIGMEC. Universidade Federal de Goiás, 2019.

MiYAdAiRA, G. H. G.; CASTRO Neto, R. M.; CARVAlHO, A. R. D. Processo de otimização multidisciplinar de aeronaves por evolução diferencial. $6^{\circ}$ FORUM SAE BRASIL AERODESIGN 2018. Sociedade de Engenheiros Automotivos, 2018.

MULLEN, A. J. Flow over an Airfoil-Geometry. Cornell University espaço SimCafé. Available at: $<$ https://confluence.cornell.edu/display/SIMULATION/Flow+over+an+Airfoil++Geometry>. Accessed on March 2, 2019.

PAIBOOLSIRICHIT, T. 3D simulation of wing fitted with Vortex Generators. 2016 Second Asian Conference on Defence Technology (ACDT). ACDT, 2016.

REIS, S. A. de C. G. N.; CARDOSO, A. B. C.; SILVA, E. H. N.; LIMA, E. L. L. Uso de túnel de vento para análise das características de arrasto e formação de vórtice em ponta de asas que utilizam winglets e asas raqueadas. $6^{\circ}$ FORUM SAE BRASIL AERODESIGN 2018. Sociedade de Engenheiros Automotivos, 2018.

SATTAROV, A.; UDARTSEV, E.; ROZBYTSKYI, V.; ZHDANOV, O. Aerodynamic performance improvement of uav by means of leading-edge vortex generators. 2019 IEEE 5th International Conference Actual Problems of Unmanned Aerial Vehicles Developments (APUAVD-2019). National Aviation University and Ukraine Section SP/AES Joint Chapter, 2019.

SESHAGIRI, A.; COOPER, E.; TRAUB, L. W. Effects of vortex generators on an airfoil at low Reynolds numbers. Journal of Aircraft, v. 46, n. 1, p. 116-122, 2009. DOI: https://doi.org/10.2514/1.36241

SØRENSEN, N. N.; ZAHLE, F.; VRONSKY, C. B. A. T. Prediction of the effect of vortex generators on airfoil performance. Journal of Physics: Conference Series, v. 524, p. 18-20, 2014. DOI: https://doi.org/10.1088/1742-6596/524/1/012019 
TURCATO, G. C. P.; PRATES, R. B.; MONTEIRO, B. T. A.; ALBUQUERQUE NETO, C. Fabricação de dispositivo de ponta de asa drooped usando programação CNC. $6^{\circ}$ FORUM SAE BRASIL AERODESIGN 2018. Sociedade de Engenheiros Automotivos, 2018.

UDARTSEV, E.; ROZBYTSKYI, V.; SATTAROV, A. Vortex flow wings. Proceedings of the National Aviation University, v. 77, n. 4, 2018. DOI: https://doi.org/10.18372/2306-1472.4.13495

ZHEN, T., K.; ZUBAIR, M.; AHMAD, K. A. Experimental and numerical investigation of the effects of passive vortex generators on ALUDRA UAV performance. Chinese Journal of Aeronautics, v. 24, n. 5, p.577-583, 2011. DOI: https://doi.org/10.1016/S1000-9361(11)60067-8

Recebido: 26 de março de 2020 .

Aprovado: 23 de maio de 2020 .

DOI:

Como citar: DUARTE NETO, J.B. et al., Vortex generators project for an unmanned small airplane, Revista Brasileira de Física Tecnológica Aplicada, Ponta Grossa, v. 7, n.1, p. 55 - 66, maio. 2020.

Contato: João Barreto Duarte Neto: joaobarretomecufc@gmail

Direito autoral: Este artigo está licenciado sob os termos da Licença Creative Commons-Atribuição 4.0 Internacional.

(c) (1) 